\title{
The Effectiveness of Charismatic Movements In Fostering New Evangelization: Case Of Vincentian Ministries In The Archdiocese Of Nairobi, Kenya
}

\author{
James Wambugu
}

\begin{abstract}
The study examines the effectiveness of charismatic movements (CMs) in fostering new evangelization: Case of the Vincentian Ministry (VM) in the Archdiocese of Nairobi, Kenya. The study focused on the research questions: How is VM an agent of evangelization? The research used the Market Choice Theory that emphasizes that conversion or recruitment is not something that merely happens to an individual. Rather it is something that the individual can deliberately achieve. We predominantly employedconvergent mixed method research designusing both quantitative and qualitative research approach. This entailed collection of primary data from a sample of 266 respondents selected through probability and non-probability sampling techniques. The findings revealed that the VM demonstrated solid or grounded treatment of the Scripture, pastoral care, catechetical instructions and witnessing. In conclusion, the study recommends dialogue with the local hierarchy, review of seminary curriculum to incorporate compulsory subject on the CMs, gifts, and charisms of the Spirit to bring dynamism in evangelization. The laity should be equally empowered through training in theology, philosophy, management and administration to promote meaningful collaboration with the ordained ministers in evangelization.
\end{abstract}

\section{Emergence of CMs}

The emergence of other (CMs) is a sporadic phenomenon in the history of the Church (Orlandis, 1993). According to Cartledge (2006, p. 33), in certain periods of church history,CMs are extremely evident. At other times, it is almost, if not totally, hidden.We now look into the Vincentian Ministry in the Archdiocese of Nairobi Kenya which is an embodiment of Catholic Charismatic Renewal Movement.

\section{The VM Centers}

Vincentian Ministries (VM) are the embodiment of CCRM in Kenya. They are a religious group originally founded by Fr. VarkeyKattarth in 1904 in Kerala India. The congregation was raised to the status of pontifical right in 1968. Vincentians are devoted to conducting retreats for renewal of faith in the Catholic Church. In the Archdiocese of Nairobi, two Vincentian retreat houses are located in Lavington and Thika.Vincentians are inspired by the spirituality of Saint Vincent de Paul, commonly known as the father of the poor. This is because of his immense desire to help the poor as in the writings of prophet Isaiah (61:1) stating, "the Spirit of the Lord is upon me, because the Lord has anointed me to bring good tidings to the afflicted, he has sent me to bind the broken hearted to proclaim liberty to the captives and opening of the prisons to those that are bound." This is an inspiring passage to the Vincentians and resonates with their mission ( Vincentian website, 23/5/2015).

Vincentians serve all people regardless of their religious affiliation. That makes Vincentians multidenominational and also multi religious. They offer spiritual guidance to both Christians and non-Christians. In the Vincentian world-view, by the "poor", meant poverty in material, spiritual and psychological realms (23/5/2015 Vincentian website).Due to the amorphous 
nature and sporadic spread of the CCRM, it would be cumbersome to really identify a group, which would fully entail the characteristics of CCRM from among Vincentians. The researcher focused on the VM participants visiting the two retreat centers during weekend fellowship over a period of a month as a representative group.

\section{Statement of the Problem}

The form of piety at the VMs is characterized by intense devotion to the Scripture, exuberant liturgical services, healing masses, prophecies and speaking in tongues among others. Undoubtedly, people from divergent walks of life throng the two Vincentian retreat centers. This seems to spark a new reawakening in the Catholic Church that has not been witnessed in the recent times. The ministry is not only attracting Catholics, but also non-Catholics; both young and old stretching in the entire East, Central Africa and beyond. To some extent, the phenomenon promotes harmony among different religions, but also regional integration.

This study seeks to investigate the influence of this form of renewal on Catholic Church which can translate to discovering a new method of evangelization suitable to the contemporary culture. The VM is seen by some as a potential new evangelization strategy in the Catholic Church, particularly in the ordinary parish life;where there are enormous challenges of reduced morale and participation in the sacramental life among unmotivated Christians, reduced number of worshippers and break-down in Christian families among other threats. Can the VM evangelization strategy be applied to situations where the Church is facing the crisis of evangelization? New evangelization can rightly be described as making the Christian message appealing again (Cordes, 1991). Consequently, this work show cases strategies used by the VM and how such strategies can be used to foster new evangelization.

\section{Research questions}

1. How is the VM an agent of evangelization?

\section{The Scope and Limitation of the Study}

This research is limited because it concentrated on the CCRM and its role in new evangelization in the Catholic Church whereas there are many other movements agitating for renewal.

\section{Theoretical Frame work}

The researcher identified The Rational Choice Theory to explain the phenomenon of the CCRM. This theory is associated with sociologists such as Rodney Stark (1934) and William Sims Bainbridge (1940; Stark, 1996). Religion is a system of compensators with a human person who is a rational actor, making choices that he/she thinks best, calculating costs and benefit. Put differently, compensators are practices that compensate for some physical lack or frustrated goal (Stark, 1996).

\section{CCRM as an Agent of New Evangelization}

\section{LITERATURE REVIEW}

Understanding and practice of mission and evangelization of the Catholic Church have changed during almost twenty centuries of the history of the Christian mission (Bosch, 2006, p 25).Paul VI (1975) thought of evangelization as a whole spectrum of complex issues, such as, "the renewal of humanity, witness, explicit proclamation, inner adherence, entry into community, acceptance of signs and apostolic initiative." In another perspective, "evangelizing" is the communication of a religious message that is intended by the evangelizer to be seriously weighed by the hearer so as to radically affect his or her spiritual center (Haughey, 1998). 
The "Great Commission" of Jesus is the mandate that triggers the activity of evangelization (Bellagamba, 1992. "Go into the entire world: proclaim the Good News to all creation" (Mark 16:15). Anybody who listens to this message and responds positively by acting on it qualifies to be an agent of evangelization.Therefore, evangelization is a meeting point between the evangelizer and evangelized (Giglioni, 1995). Just as the evangelizer is vigorously involved in the proclamation of the Gospel, the recipient is actively involved in accepting or rejecting the message. The success of evangelization can be weighed against the recipient who is not passively involved in welcoming the message but also discreet in making choices whether to welcome or ignore the message (Cordes, 1991). Put differently, the message of the Gospel cannot become gross, but that the evangelizer can be repulsive.

Today, "new evangelization" is a common expression and probably one among the most used phrases in the Church today. Newevangelization can be rightly called a process through which the Church in its entirety is made appealing again to people (Cordes, 1991). As Paul II, (1999, p. 95)puts it, "The new evangelization is to be new not in content, but in ardor, methods and expressions". Whereas the core teachings and values of the Church remain uncompromised, the ways of doing or disseminating such values are reevaluated. This comprehensive process produces a new paradigm of evangelization now called new evangelization. Seemingly, this is ad infintum process at which the entire Church must remain engaged at all times. The adage that the Church is always in need of reformation then carries weight in the process of new evangelization (AMECEA,1995).

\section{RESEARCH DESIGN AND METHODOLOGY}

The study utilized the convergent mixed method research design. This is a design that focuses on collecting, analyzing, and mixing both quantitative and qualitative data in a single study or series of studies. Its central premise is that the use of quantitative and qualitative approaches, in combination, provides a better understanding of research problems than either approach alone(Creswell 2014).

\section{Target Population}

In this research, the target population comprised all the lay, clergy and religious individuals who participated in liturgical activities of the VM in the Archdiocese of Nairobi. The priest incharge of the VM on $18^{\text {th }}$ August 2016, estimated about five thousand (5000) people attended and participated in VM activities in Nairobi.

\section{Demographic Information}

DATA PRESENTATION AND DISCUSSION OF THE FINDINGS

The demographic data delineated variables which were of interest to this study: were gender, age, level of education and occupation of all the respondents. Let us now discuss the data with respect to these variables.

\section{Gender of Participants}

Information about the gender of the VM members and leaders plays a key role in this research. Its aim was to answer the research question on the characteristics and teachings of VM. When gender participation in the VM is heterogeneous, it could reveal some characteristics and teachings of the VM that resonate or meet the spiritual needs of women as well men in the Church. All respondents in this study were asked to indicate their gender. Data obtained in their responseis as summarized in Table 4.1. 
Table 4.1: Gender of Respondents

\begin{tabular}{lcccc}
\hline Gender & \multicolumn{2}{c}{ VM members } & \multicolumn{2}{c}{ VM leaders } \\
& Frequency & Percent & Frequency & Percent \\
\hline Female & 164 & 65.6 & 9 & 56 \\
Male & 86 & 34.4 & 7 & 44 \\
\hline Total & $\mathbf{2 5 0}$ & $\mathbf{1 0 0 . 0}$ & $\mathbf{1 6}$ & $\mathbf{1 0 0}$ \\
\hline
\end{tabular}

Table 4.1 clearly shows that majority of VM members who participated in the study were female $(66 \%)$ while $34 \%$ were male. In the VM leadership, most of the participants were likewise female (56\%); the remaining 44\% were male. This means that females are numerically predominant in the VM. These findings dovetail with (Hockens, 2003; Maurer, 2010) which found out that female members and leaders formed the majority of those who participated in the CCRM activities. For instance, leadership in the CCRM has given women sizable roles that were predominantly occupied by men (Hockens, 2003; Maurer, 2010). This goes along with the (Mooney, 2004) vision of contemporary church gender participation.Scholars have lauded participation of women in VM they urge that their voices should be accorded respect at every level of church life - in parishes, dioceses, assemblies and conferences and in church councils for effectively building of the Church. Such recognition could compensate for centuries of apparent subordination and forced supervision of women by their male counterparts. In such a dispensation, women are equal partners to men in evangelization (Mooney, 2004).

The dominance of women in VM leadership is a valuable finding in this research.In terms of visitations to the $\mathrm{VM}$, the data presented in Table 4.2 shows that most of the female participants made weekly and monthly visits while the male participants visited once in a while. The study demonstrates that women frequent the VM more times than men. The frequency and robust participation in VM could signify the availability of women to participate in the VM activities than men. Alternatively, it could reveal that women have more pressing spiritual needs than men, hence they are encouraged to participate more frequently because their needs are effectively met at the VM.

\section{Age of Participants}

The study was also interested in obtaining information about the age of the participants. The data on age of the respondents plays an important role in explaining the participation of the VM members and how they are affected by contemporary challenges of faith.Apparently, people from different age categories have varied spiritual and physical needs. Data obtained from all participants about their age is presented in Table 4.3.

Table 4.2: Age Distribution of Participants

\begin{tabular}{lcccc}
\hline Age & \multicolumn{2}{c}{ VM members } & \multicolumn{2}{c}{ VM leaders } \\
& Frequency & Percent & Frequency & Percent \\
\hline $15-20$ & 5 & 2.0 & 0 & 0 \\
$21-25$ & 46 & 18.4 & 0 & 0 \\
$26-30$ & 76 & 30.4 & 3 & 19 \\
$31-35$ & 36 & 14.4 & 4 & 25 \\
$36-40$ & 29 & 11.6 & 3 & 19 \\
$41-45$ & 20 & 8.0 & 1 & 6 \\
$46-50$ & 17 & 6.8 & 2 & 13 \\
Above 50 & 21 & 8.4 & 3 & 19 \\
\hline Total & $\mathbf{2 5 0}$ & $\mathbf{1 0 0 . 0}$ & $\mathbf{1 6}$ & $\mathbf{1 0 0}$ \\
\hline
\end{tabular}


Table 4.3 demonstrates that majority of the VM members (76\%) were aged between 21 and 40; 63\% of the VM leaders were aged between 26 and 40 . However, 32\% of the VM leaders were aged 46 and above. This means that the VM was attracting mostly younger members in the society. Miller(2013), earlier found out that majority of the youth were frustrated and neglected in the society aswell as in the Church. This was because their aspirations and resentmentswere not catered for or regularly voiced out in the traditional Catholic churches. Pope Francis who sadly felt that the youth failed to find responses to their concerns, needs, problems and hurts in the usual structures equally echoes this(EG, 104). The presence of the youth as majority participants in this study reveals their hope that their interests, aspirations and concerns are taken care of in the VM.

\section{Education Level and Occupation of the Participants}

Data on the education and occupation of the participants plays an important role. This was soughtto explain how the economic status affected participation in the VM. Data gathered in the study in this respect is summarized in Table 4.6.

Table 4.3: Education Level of the Participants

\begin{tabular}{lcccc}
\hline Level of education & \multicolumn{2}{c}{ Church Leaders } & \multicolumn{2}{c}{ VM Members } \\
& Frequency & Percent & Frequency & Percent \\
\hline Primary & - & - & 9 & 4 \\
Secondary & - & - & 32 & 13 \\
College & - & - & 98 & 39 \\
University & 13 & 81 & 109 & 44 \\
Others & 3 & 19 & 2 & 1 \\
\hline Total & $\mathbf{1 6}$ & $\mathbf{1 0 0}$ & $\mathbf{2 5 0}$ & $\mathbf{1 0 0}$ \\
\hline
\end{tabular}

From Table 4.6, majority of the VM members (83\%) who participated in this study were of college and university levels of education; $81 \%$ of VM leaders were university graduates.This means that VM attracted a majority members and leaders who had attained some education level of college and above. These study findings do not correlate (Shorter, 2003, p. 15; Chestnut, 2003) studies conducted on CMs in Africa. Most CMs in Africa are dominated by people who are considered down-trodden and whose aspirations and struggles are alien to the mainline churches (Omenyo, 2004). Thus, CMs are naively despised as belonging to the people that are disadvantaged in the society (Shorter, 2003, p. 15; Chestnut, 2003). There are some similarities between the birth of the CCRM and the establishment of VM. Apparently,(Gallagher, 2013) confirmed that the CCRM was borne from a university environment The phenomenon of educated persons' participation in VM could as well indicate that even educated persons were interested in experiential faith. Further, the study reveals that increasingly, there are people with degrees equivalent to those earned by the ordained clergy (Mooney, 2004).

\section{Denomination and Residence of the Participants}

The influence of residence and the denomination of the participants in VM were important in this study. They could help to reveal the cross denomination profile. A measure of the extent to which participants of various denominations from either rural or urban areas engage in VM activities can demonstrate the possibility of the promotion of ecumenism in the Archdiocese of Nairobi, which stretches in both urban and rural areas. 
Table 4.2: Denomination and Residence of the Respondents

\begin{tabular}{llccc}
\hline Denomination & & \multicolumn{2}{c}{$\begin{array}{c}\text { Residence of the } \\
\text { Respondent }\end{array}$} & Total \\
& & Rural Area & Urban Area & \\
\hline \multirow{2}{*}{ Catholic } & Frequency & 25 & 212 & 237 \\
& $\%$ & 10.0 & 84.8 & 94.8 \\
\multirow{3}{*}{ Protestant } & Frequency & 1 & 8 & 9 \\
& $\%$ & 0.4 & 3.2 & 3.6 \\
\multirow{2}{*}{ Pentecostal } & 1 & 3 & 4 \\
& Frequency & 0.4 & 1.2 & 1.6 \\
\hline \multirow{2}{*}{ Total } & $\%$ & $\mathbf{2 7}$ & $\mathbf{2 2 3}$ & $\mathbf{2 5 0}$ \\
& Frequency & $\mathbf{1 0 . 8}$ & $\mathbf{8 9 . 2}$ & $\mathbf{1 0 0 . 0}$ \\
\hline
\end{tabular}

Table 4.9 shows that majority of VM members who participated in the study were Catholics (95\%); the remaining 5\% were Protestants, which included Pentecostals.The results apparently resonate with other studies where Pentecostals spurred the CCRM; making a hybrid of traditional Catholicism and Pentecostal tendencies, which attracted a small representation of the Pentecostals and Protestants in the VM (Cox, 1996). The presence of people from other denominations is an invaluable opportunity to initiate ecumenism. This could eradicate bitter rivalry that sometimes characterizes and inhibits healthy relationships among Christians.

\section{The VM as an Agent of Evangelization}

The term evangelization carries various definitions, some, which are inadequate to exhaust the full meaning of the term as used in this study. For the purpose of this study, the term evangelization was defined as a conglomeration of multiple activities such as, "the renewal of humanity, witness, explicit proclamation, inner adherence and entry into a community, acceptance of signs and apostolic initiative"(Paul VI, 1975).In this regard, the researcher sought for information on the various activities conducted by the VM that befit evangelization as defined.

\section{Proclamation Based on the Scripture}

The researcher sought for information from the respondents about the extent to which Scripture is used in the VM in relation to how the clergy and the laity proclaim the good news. Scripture is important in evangelization, it is therevealed truth. Scripture leads one to the primary call of Jesus to His disciples during the Great Commissioning (Mark 16:15).St. Paul in his Epistles to the Romans (10:14-15) raises many questions concerning the importance of Scripture and proclamation:

How then can they call on the One they have not believed in? And how can they believed in the One of whom they have not heard? And how can they hear without someone to preach?And how can they preach unless they are sent?

This is a clear manifestation of how important Scripture and proclamation is to the Christian.

Ideally, without Scripture and proclamation, there is no meaningful Christian theology or evangelization.

Vatican II Council buttressed the centrality of the scripture by asserting that every theological reflection, preaching or evangelization must beget its origin from Scripture (DV, 1965,1). Information regarding this question was obtained from the VM clergy and the laity through IDIs. Five out of eight laity interviewedin the FGD on $16^{\text {th }}$ December 2016, shared a common view that the VM taught the Bible and encouraged Christians to read it on their own as a norm 
for Christian living. To achieve this, Christians were provided with monthly Bible verses or quotations to read and meditate on in the context oftheir life experience. Once Christians read and reflect on the Scripture passages, on volition, one could go for more Bible verses from the clergy.

Such biblical passages are provided by the clergy based on the spiritual needs of an individual Christian. After reading through the given biblical passages, they would discover on their own how to overcome their life predicaments. Thisexercise is meant to heighten the knowledge of Scripture by the Christians. In support to this notion, (Male respondent\# 06, Lavington community $16^{\text {th }}$ December 2016) intimated that, "The Scripture is the norm and the background of the VM teaching in which I draw spiritual insights. The priests are conversant with Scripture and spontaneously give verses for reflection as per the needs of the person".

Similarly, (Female respondent \#07, Lavington community, 16 th December 2016)added, "The VM sellsChristian community Bibles to the laity at a reasonable price so that each Christian can own a Bible. This has encouraged more Christians to own and read the Bible in the church and at homes". To emphasize on the values the laity attach to owning a Bible, (Male respondent \#08, Lavington community $16^{\text {th }}$ December2016)noted, "The VM is highly committed to teaching of Scripture, ensuring that it reaches to all the laity in the simplest way possible. That is why Scripture is taught to the attendants by drawing themes of forgiveness and inner healing, among others".

The role of the Catholic ordained minister and laity interacting with the Scripture is a sensitive issue in the history of the Catholic Church. Some of the Christians believe that the Bible is a complex book. Accordingly, it would be harmful to expose the Scripture to the laity because they are not trained in interpreting it (Brockman, 2010). Consequently, this fear has led to a number of the laity failing to read the Scripture on their own (Sullivan, 1982). This view has implicitly dominated the traditional Catholic Church and created a dependency syndrome of the laity on the ordained ministers in interpreting the Bible. This has crippled the enthusiasm of the laity to read Scripture. Christians perceive the interpretation and the reading of Scripture to be solely the work for ordained ministers. Although this view controls interpretation, it is counterproductive because the Bible is perceived as a scientific book rather than a revelation, an instrument of God's grace to convert people through the aid of the Holy Spirit.

Unlike in traditional Catholic Church, Protestant and Pentecostal churches allow and encourage all the Christians to read and interpret the Scripture as the Holy Spirit guides them. In these churches, the Scripture is taken as revealed truth, which can bring conversion through the aid of the Spirit (Kung, 1979). The VM seems to have combined the two models, thereby giving the laity an opportunity to make the Bible meaningful and a source of drawing insights to their spiritual challenges. Individual VM Christians can, therefore, read and interpret the Scripture for their own personal or communal growth. They have a special devotion to the Scripture and Christians are encouraged to read the Scripture. The Scripture is pivotal in every theological reflection (DV, 1965) as it also shapes people's lives from within towards God (Magesa, 2016).

The Bible is unique in that it evokes the feelings of universal recognition and application, which are timely and touch on the core of every man and woman (Hollenweger, 1998). The importance of the Scripture in evangelization is indispensable. By enabling the Christians to read and interpret the Scripture, the VM is inviting them to become evangelizers. God's Word has its own energy and power to spark faith even in contemporary contexts. 


\section{VM Retreats and Recollections}

Information about the VM retreats and recollections was equally important for this study. This is because it would reveal the extent to which the Christians and non-Christians from all walks of life encounter the VM clergy in the closest way possible. The possibility of frequent affordable retreats and recollections conducted by the VM was an intriguing phenomenon observed during data collection. This revealed that the retreats and recollections are not only fostering evangelization in the Christian faith, but also human renewal through indiscriminate services to all. (Clergy respondent \#08 in Thika on 3 September 2016) noted, "The Thika center was established to cater for residential retreats, it has sufficient facilities to host five thousand retretants. Since the facility was established, the VM has continued to minister to more people that they could previously do in the Lavington center". This demonstrates how vibrant the VM is to evangelize in the contemporary world. (Female respondent \#05 Lavingtoncommunity, $16^{\text {th }}$ December 2016) added that:

The VM organizes different types of retreats and recollections that are transformative in nature. Fridays are reserved for general recollection in Thika and Saturday in Lavington Center. Christians and non-Christians stream in huge numbers into the VM facility for commencement of the day of recollection during which adoration, instruction, counseling, confessions and the Holy Mass are conducted.

Data collected from the documents and existing records from the two retreat centers revealed thatspecific retreats and recollections were scheduled on different intervals in the entire year. This information was easily accessible through the VM annual calendar and website. This was attested to by (Female respondent \#03 in Lavington community on 16 December 2016) observed that, "Retreats are organized according to the special needs of individuals, groups, youths, religious and couples. Participants are charged a flat rate of three hundred and fifty (US \$3.5) per week. This has made retreats possible for all”. In addition, (Female respondent \#06, Lavington community $16^{\text {th }}$ December 2016$)$ noted:

If one could consider that Christians pay shillings 2000 for a full board retreat in some religious retreat centers, one can realize that the VM is not money oriented.That is why people give their financial support generously to keep the VM alive.

It was also found out that the VM does not charge any monies from the laity during recollections. (Female respondent \#04 Lavingtoncommunity $16^{\text {th }}$ December 2016) remarkedthat,

The VM provides free water, bread and tea during the recollections. This gesture enables the people to persevere the long hours of recollection without succumbing to thirst and hunger, which could send them away hence abandoning the event.

The VM and well-wishers financially support retreats according to the VM clergy. (Male respondent \#05 in Lavington community on $16^{\text {th }}$ December 2016) intimated, "Retreats are forums through which many healing takes place; they teach about God; inner wounds are healed; catechesis and counseling sessions are conducted". The researcher further interrogated the laity on the effects of such recollections and retreats to the attendants. To this effect, (Female respondent 01, Lavington community $16^{\text {th }}$ December 2016) added that:

I had left the Catholic faith thinking that it is boring. But after attending retreats, I learnt about the importance of the Catholic Mass. VM gave me answers to the questions. I developed a sense belonging. I am transformed to a better person, from such a critical and unforgiving Catholic who was not receiving the sacraments to a Christian who understands the need to be with the help of sacraments to receive the grace mercy and forgiveness. 
The research finding has demonstrated that the VM retreats are affordable. When compared to other religious communities where retreats are exorbitant, charging a minimum of two thousand Kenya shillings (US dollars 20) per person per day. Although the VM has very modest facilities, it is fascinating to realize more people prefer conducting retreatsin the VM centers than other religious centers. This is for the obvious reason that they are affordable and beneficial to the spiritual needs of the Christians. Further, conducting frequent retreats and recollection is geared towards constant reawakening of faith or simply renewal of people. It is a forum for building daily bridges between the gift of God in Christ and the limited realities of each one's life. The faithful give attention to the call of the Spirit, where they shape the quality of their Christian journey, where they protect the freedom of their hearts, and where they learn to struggle amid the pressures of life (Kasper, 1982).

The findings on frequent retreats and recollections are supported by(Gallagher, 1998). His study demonstrates that the CM and the CCRM have a tradition of organizing conventions at local and international levels in order to spur faith. CM members that are economically endowed contribute immensely to enable the less privileged to attend. Such conventions create sufficient synergy, which revives the faith of the attendants (Gallagher, 1998). The importance of retreats and recollections in evangelization cannot be overemphasized. They create a suitable environment for Christians who share a common heritage to invigorate faith in their lives. It is a strategy of evangelization when the ordained minister and the laity constantly engage in proclamation of the Word, exhortation and in encouraging those who are weak in the Christian faith. The problems, joys and struggles of the people of God are inherently a concern for evangelization.

\section{Counseling and Pastoral Care in the VM}

Regarding counseling, the researcher engaged the laity and the clergy on the spiritual aid given to non-Catholics who could not participate in the sacramental life in the Catholic Church. This question was important because the data obtained would help explain reasons that attract some non-Catholics to VM. From the FGD held Lavington on 16 ${ }^{\text {th }}$ December 2016, six out of eight discussants were of the opinion that:

$V M$ conducts numerous counseling sessions for people from other denominations and religions who canonically cannot receive the sacrament of confession or any other sacrament. This gesture has reverted people from other denominations and religions to Catholic faith.

(Male respondent \#07, Lavington community $16^{\text {th }}$ December 2016) noted that "VM provides spiritual mentorship and guidance which lead me to understand my problems. Through VM, I can confess that I have received inner healing and learned how to adore and pray". Female respondent \#04, Lavington community $16^{\text {th }}$ December 2016)added her voice in support of the same opinion saying, "I had left the Catholic faith thinking it is boring but after attending retreats organized by the VM, I came to appreciate the importance of the Catholic Mass". Mooney (2004) calls for ongoing formation of the laity as indispensable in empowering participation in the parish life.

According to LG(4), the Church is an institution of God's love whereby the joys, the pains and the struggles of the human being ought to be at her center. Information about whether VM is people centered or not is of paramount importance to this study. Data on this aspect was collected from the laity and clergy through interviews. In an FGD held in Lavington community on the $16^{\text {th }}$ December 2016, five out of eight interviewees expressed a common view that the VM was inspiring and deeply connected with people's lives. Liturgical activities were conducted in a manner that was fulfilling the participants. Further, they are in tune with the 
spiritual quest of the contemporary society while motivating and encouraging those facing life challenges.

(Female respondent \#05, Lavington community, 16 ${ }^{\text {th }}$ December 2016) pointed out, "In the VM, people experience the presence of God and rely on God's providence". While (Male respondent 01 Lavington community, 16 ${ }^{\text {th }}$ December 2016) noted that "VM enlightened him to understand the meaning of the term, mercy of God and that no matter how sinful or broken one was, there is always need to forgive". This view was also supported by the words of (Male respondent 03 Lavington community 16 December 2016) remarked that:

In the VM, I found out a conducive environment to pray. I was sensitized on how to recognize the power of prayer through vigorous praise and worship combined with freedom of praise and expression of feelings. At one prayer session, through intercessory practices and devotions, I found myself crying uncontrollably, singing and raising hands.

Despite these numerous appraisals of the VM in embracing people-centered approach to the ministry, a number of reservations were raised. For instance, (Female respondent \#01 Lavington community $16^{\text {th }}$ December 2016) commented that:

The center of VM ought to be Jesus Christ and not the people. I have participated in many prayer sessions, and have never felt at peace when people cry, shout and dance while praying. I believe this behavior in church must not be tolerated.

Generally, the VM is all inclusive each person has opportunity to discover him/herself an experience of God. Undoubtedlyone could realize his or her own orientation and the best way to serve the Church/God in different capacities. Depending on individual gifts (RM, 1995).Conducting counseling and pastoral care is one of the dimensions of evangelization following the comprehensive definition that was provided by Pope Paul VI. It digs deeper in encountering the Christians and non-Christians at their level. This means that the VM is concerned with the plight of humanity, a fundamental step for an agent of evangelization.

\section{Addressing Devastating Challenges in the VM}

According to GS $(1965,4)$, it is the responsibility of the Church to address the remotest and most devastating challenges a Christian community can face.

To carry out such a task, the Church has always had the duty of scrutinizing the signs of the times and of interpreting them in the light of the Gospel. Thus, in language intelligible to each generation, she can respond to the perennial questions, which men ask about this present life and the life to come, and about the relationship of the one to the other. We must therefore recognize and understand the world in which we live, its explanations, its longings, and its often dramatic characteristics.

There are many challenges that were mentioned by discussants in the FGD held on $16^{\text {th }}$ December 2017 in Lavington Hall. These included broken marriages, sickness, joblessness and personal crisis. The respondents attributed the source of such inflictions to witchcraft. This is the reason why the researcher presents witchcraft as a serious estrangement, which VM has addressed amidst others. Apparently, due to its devastating nature, witchcraft places a demand upon the Church to offer a solution if not, the laity may be forced to seek help elsewhere. The data to this question was obtained from the laity through interviews. Addressing the issue of witchcraft and how it is dealt with in the VM, (Male respondent \#05 Lavington community $16^{\text {th }}$ December 2016) remarked:

VM dares to penetrate into areas that are buried deep into our African Christian unconsciousness on the grounds of denial and helplessness. Many reported cases of 
witchcraft have been dealt with in the VM to the admiration of most of the laity. Unlike in VM many reported cases of witchcraft are hardly addressed within conventional Catholics.

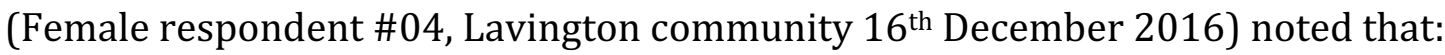
Christians continue to narrate in many occasions how forces of witchcraft devastated them, but when such estrangements are addressed in VM, there is a deep sense of relief and hope generated from the reassurance that God is indeed more powerful above the malignant forces of evil.

The success of the VM in confronting vices such as witchcraft among others, must be probed carefully. In African Traditional Religion, there were provisions that would resolve spells that were associated with witchcraft. Recognized medicine men / women who were appreciated by their communities provided such solutions. Can an African oriented challenge be resolved through an African recognized solution? Despite such success stories narrated by the laity over witchcraft, (Male respondent \#07, Lavington community 16 December 2016) interjected, observing that: "Many of these claims of people being healed from witchcraft cannot be proved and therefore I consider them as baseless allegations". Many African scholars discuss witchcraft extensively as a force that reduces vitality (Mbiti, 1997; Magesa, 1997; Mulago, 1969; Majawa, 2007). The VM capacity to address most devastating challenges is a demonstration that they are capable of accompanying the Christians whenever they experience even other lesser estrangements.

Despite the various ways in which the VM addresses cases of witchcraft, there is no comprehensive pastoral approach developed yet to mitigate it in the Archdiocese of Nairobi. However, the VM has introduced a language that draws African Christians to the knowledge of dark forces of witchcraft. In this language, the focus is on the power of God who is greater than dark forces of witchcraft. Christians are encouraged not to visit diviners, traditional healing practices, but focus on the power of God discovered through faith in the cross of Jesus and in the sacraments particularly of the Eucharist.

As a Catholic priest, the researcher is informed of summary condemnationof witchcraft in the conventional Catholic Church without a single explanation. Sometimes, Christians continue to visit traditional healers secretly. This is a miserable failure on the part of the Church to engage holistically and honestly the Africans in their estrangement (Magesa, 2016; Lienhardt, 1982; Pembe, 1980). It is relevant in this dispensation to envisage African values in the contemporary evangelization particularly when addressing devastating challenges.

\section{Catechetical Instructions in VM}

The study was also interested in finding out the ways in which VM repackages the Catholic catechetical instructions, making it relevant to contemporary Christians. Apparently, the old methodology of presenting basic instructions for catechesis as found in the CCC was heavily philosophical and theological.Such language was found not pleasant to a great number of Christians as they found it difficult and discouraging. For instance, the CCC is divided into four parts: profession of faith; celebration of the Christian mystery; life in Christ; and Christian prayer. In the profession of faith, the CCC, 296 describes ex nihilo, "creation out of nothing" as follows:

We believe that God needs no pre-existent thing of any help in order to create, nor creation of any sort of necessary emanation from the divine substance. 
The phrase 'creation out of nothing' is not found in the Scripture, rather it is a philosophical and theological language where the Scripture uses the plain language that God created (Genesis 1:1). Further, the usage of the term emanation from divine substance falls in the same philosophical and theological categories. Another challenge with catechetical books is that they are subject to reviews, which take place after a long time. For instance, the CCC that was published in 1995 was reviewed in 2001 and reprinted in 2007. Comparing the different publications and reviews, the language used remained predominantly philosophical and theological. This demonstrates that an ordinary Christian needs to be equipped with basic philosophy and theology to grasp the meaning of such descriptions. In this regard, the editions of catechetical books have remained less comprehensible to Catholic needs.

These concerns further imply that there is need to write local catechisms, taking into account the various situations and cultures while preserving the unity and fidelity of the Catholic doctrine. The VM has brought on board a new book titled 'Catholic Catechism for All' (Parankimalil, 2006). Although the book has some challenges in adapting to divergent methods of instruction, it is a step ahead in the realization of catechism. In order to obtain this information from the laity and clergy, IDIs were conducted and the responses analyzed through narrations and quotations. In the FGD held in Lavington on 16 December 2016, seven out of eight discussantsshared the common view that many Catholic Christians were ignorant of fundamentals of the Catholic teachings due to lack of proper instructions. In response to this need, VM has taken the initiative to educate Christians in all aspects of Christian faith. In so doing, Christians felt quite illumined in the Catholic doctrine

The VM is using the apparent weaknesses found in the traditional Catholic Church as a springboard to new evangelization. It is creating new approaches to catechesis of the Catholic Church. In support to this, a (Male respondent \#05 Lavington community $16^{\text {th }}$ December 2016) commented; "The VM makes the members of the CatholicChurch proud of their faith. Some basic faith teachings and norms of the Catholic Church have been made easy for the understanding of all members regardless of their educational levels". Five out of eight interviewees in IDIs expressed their personal fulfillment after receiving catechetical instructions

from the VM. (Female respondent \#04, Lavington community, 16 $6^{\text {th }}$ December 2016) expressed her opinion: "The VM has inculcated moral values and Catholic doctrines to me in a better way than when I was instructed in the traditional Catholic catechism. This has made the mysteries of faith easy for me to understand".

More interviewees gave various experiences of how the VM had simplified the catechetical instructions for the laity. (Female respondent \#06, in Lavington community, $16^{\text {th }}$ December 2016) for instance noted that:

VM teachings have made the power of the Holy Spirit to be felt in the Christian community. The sacraments have been made more meaningful, especially the one of reconciliation. I can sincerely say that I make good confessions unlike before; I can attribute this to the way the clergy spends amble time in giving instructions and placing more emphasize on the power of the Holy Spirit. I have now understood more about receiving the Holy Eucharist with reverence and making sincere repentance by identifying sins that I commit guided by the Ten Commandments.

The sentiment captured above is an indication that the VM is rediscovering sacraments and the Holy Spirit. The Catholic Church is perennially accused of silencing the voice or neglecting the discourse on the Holy Spirit (Kasper, 1982). This is also a predominant challenge when the 
Church is institutionalized. It is important that the voice and the discourse of the Holy Spirit are rediscovered. The Spirit is the main agent of evangelization. Whenever VM is reviving the voice and rediscovering the Spirit, it also renews its resolve to evangelize. (Female respondent \#06 in Lavington community on $16^{\text {th }}$ December 2016) noted:

The VM is more vocal in ensuring that the Catholic doctrines are upheld. We are given instructions on the Bible, rosary, and rubrics (e.g. genuflecting in the church). Using strong Biblical support, they teach us on images, icons, the Trinity, saints and angels. I feel that the big theological terms are quite simplified for common understanding of all the laity.

In response to the effect of the VM's catechetical teachings on their faith, (Male respondent 02 in Lavington on 16 ${ }^{\text {th }}$ December 2016) observed that "In the VM, the focus on the Catholic faith is so amazing that it has made me improve my knowledge of the Bible and live the Catholic doctrines in a simple way". In support to their teaching catechism, (Clergy respondent 05 in Thika 16 August 2016) had this to express:

Catechism is strengthening the Catholic Church in renewal of faith. I put more emphasis on the themes found in the Catholic catechism such as ecclesiology, liturgy, devotions and sacramentology. In this way, Christians can deepen their faith and maintain a good relationship with the hierarchy of the church.

(Female respondent 02 in Lavington community on the $16^{\text {th }}$ December) confessed that: I have learnt about the love of God and our neighbor. I now understand the sacrament of reconciliation, adoration, the Virgin Mary as well as intercession through angels and saints. I understand Mass, which I was not able to decipher before since I did catechism at a tender age. I become rich in my Catholic spirituality and not the way Protestants describe Catholics.

(Male respondent 06 on the $16^{\text {th }}$ December) opined that:

$V M$ has taught Christians intensely on sacraments and through that teaching, many laity have wedded in their respective parishes. My aunt who was a Muslim, got baptized after attending catechetical classes with VM and confessed to the church that she was more enlightened than ever before on the Christian faith. This confirms to me that VM is the best place to capture the Catholic faith with understanding of suffering and purity.

The researcher lauds the catechism taught in the VM. It deviates from the catechetical instructions that dominate the Church, based on memorizing catechetical formulas repeating and assimilating doctrinal claims and creeds without questioning them (Ilo, 2016). Such model of catechetical instruction is quite repulsive particularly to adults interested to deepen faith. The researcher observed in the VM, a different methodology of administering catechetical instructions on prayer, sacraments, Bible and Christian morality that is integrated with people's experiences while at the same time retaining the identity of Catholic teachings.

\section{Witnessing of the Laity and Priests in VM}

The researcher also investigated aspects of witnessing of the priests and the laity in the VM. This question revolved around the authenticity of the Christians whereby the profession of faith is accompanied by appropriate action in the ethical and moral life of a person. Data collected from the laity and the priests through interviews were abounding with examples of honesty and integrity manifested through witnessing by the laity and the priests concerned. There were indicators that point to honesty. For instance, they were not demanding for money from those who benefitted from the VM. Further, they are not riddled with scandals, which 
negatively impact the evangelization process. All the eight intervieweesin the FGD in Lavington Hall held on the $16^{\text {th }}$ December 2016 shared a common view that the priests were available in conducting their ministries and were equally holy and committed to their calling.

(Female respondent \#01, Lavington community $16^{\text {th }}$ December 2016) narrated about her first encounter with the VM priests and how they assisted her recovery from sickness:

I was going through a crisis that slowed my life. I was constantly sick and the doctors could not diagnose my condition. Dejected and abandoned, I decided to seek help from the much talked-about Lavington VM Center. Every day, I visited the center, I would find the VM priests in the adoration chapel deeply in prayer. This encouraged me to pray and meditate over my predicament, with time, I got miraculously healed. The VM priest left an indelible mark of holiness due their commitment and witnessing.

Two observations can be made regarding the narrative above. On one hand, the lady felt that the priests were committed to prayer and participation in the rituals. On the other, she attributes her healing to God through the intervention of the VM. There is a connection between faithful participation and God's miraculous participation. The (Female respondent \#01) rediscovered God after observing the dedication of the VM priests. Subsequently, she got healed.

Priesthood is a demanding responsibility, but the VM priests are dutifully required to live according to their calling. Through their simple way of life, the priests accommodate both Catholics and non-Catholics alike, focusing on saving souls. (Male respondent \#04, Lavington community $16^{\text {th }}$ December 2016 ) opined:

VM maintains a healthy boundary between themselves and the laity. They do not entangle with sensational issues that could bring tension or provoke unhealthy relationship with the laity nor promise money, or favors or anything that would make them appear as the source of help. They do not accept petty cash but request those with intentions of making contributions to participate in the some projects in the ministry.

It is remarkably important when ministers are committed to their responsibility. Apparently, Pope Francis (EG, 24) called the pastors to "take the smell of the sheep" then the sheep will identify themselves with him and listen to him willingly. Commitment to the ministry is the first step for a pastor to enter into the "smelly" world of the sheep (Arinze, 2012). Pope Francis buttresses the importance of the availability of priests to Christians and exhorted that keen listening and understanding were a basic step in evangelization.

The research question sought to discover if the VM was an agent of evangelization. The study findings revealed that the VM was involved in various activities of evangelization. Such as proclamation based on the Scripture, retreats and recollections, sacraments of Eucharist and confession. In regard to counseling and pastoral care the VM gives attention to devastating challenges, catechetical instructions and witnessing of the laity and the priests. These activities resonated well with Paul VI's definition of evangelization thatevangelization as a whole spectrum of complex issues, such as, "the renewal of humanity, witness, explicit proclamation, inner adherence, entry into community, acceptance of signs and apostolic initiative." Engagement in such evangelization activities has madethe VM an agent of evangelization in the Archdiocese of Nairobi. 
The study looked into the effectiveness of the VM as determined by the indicative practices that attract people to the ministry. A regression analysis $(Y=A+B X+E)$ was conducted and the results are summarized in Tables 4.22 .

\section{Testing the hypothesis}

Table 4.22: Model Summary

\begin{tabular}{|l|r|r|r|r|}
\hline Model & \multicolumn{1}{|c|}{$\mathrm{R}$} & R Square & \multicolumn{1}{|c|}{$\begin{array}{c}\text { Adjusted R } \\
\text { Square }\end{array}$} & Std. Error of the Estimate \\
\hline 1 & $.888^{\mathrm{a}}$ & .788 & .786 & .242 \\
\hline
\end{tabular}

a. Predictors: (Constant), Pentecostal practices of Vincentians

b. Which Attracts you

Data in Table 4.22 shows an R-square value of 0.788 , indicating that the two predicators: Pentecostal practices of VM and what attracts the laity to the VM, explains about $79 \%$ (0.788x100) change in the effectiveness of the VM.

\section{RECOMMENDATIONS}

The ordained ministers in the Archdiocese of Nairobi should be trained on professional counseling skills in order to address various challenges afflicting Christians in the church today. However due to pastoral engagements in the parishes, the Archdiocese of Nairobi should in liaison with institution of higher learning. To enable priests to study in-service programs which can provide them with counseling skills which can enable them meet the ever increasing demand of counselling.

The Catholic Church in Kenya should review various essential Catholic doctrines such as theologies, philosophy, spirituality and traditions. This processshould be conducted by the church hierarchy and theologians. A commission can be set comprising all the pastoral agents of the Catholic Church in order to improve on inculturation. Further, serve adequately the changing needs of the society.

The Catholic Archdiocese of Nairobishould construct renewal facilities. Such facilities are meant to address the needs for renewal by the laity through retreats, seminars and bible study among others. The Archdiocese must take into consideration the cost of individual participation order to make sure that such facilities are affordable to the great number of Christians who are struggling with economic hardships.

The Catholic Church should focus in re-evangelization that revolves around transforming a human person through material and spiritual promotion to reinforce authentic Christian faith. The Church should amplify use of modern means of social communication in order to spread the salvation message to humanity. The Archdiocese should embrace the use of modern communication technology in evangelization. The VM should consider investing in radio and a television stations in order to promote tele-evangelism instead of opening more renewal centers.

\section{CONCLUSION}

The study looked into diverse ways in which VM is an effective agent of evangelization. This is a multi-dimensional reality, however VM has successfully used proclamation based on the scripture; retreats and recollections; counseling and pastoral care; addressing devastating 
challenges; catechetical instructions and witnessing of the priests and the laity. This study further reveals that the techniques applied by the VM in evangelization are in tandem with contemporary society inspirations. The Gospel remains the same but the manner of presentation is different in order to accommodate the contemporary culture. This study recommends the VM style of evangelization to the entire Church for effectiveness in evangelization.

\section{BIBLIOGRAPHY}

Bellagamba, A. (1992). Mission and Ministry in the Global Church, New York: Orbis Books.

Bosch, D. J. (2006).Transforming Mission: Paradigm Shift in Theology of Mission. New York: Orbis Books.

Brockman, N. \& Pescantini, U. (2010). A History of the Catholic Church, Nairobi: Pauline Publications.

Cartledge, M. J. (2006). Encountering the Spirit the Charismatic Tradition in Traditions of Christian Spirituality Series, New York: Orbis Books.

Cordes, (1991). Call to Holiness; Reflection on the Catholic Charismatic Renewal, Collegeville, Minnesota: Liturgical Press.

Gallagher, M.P. (2013). Clashing Symbols: An Introduction to Faith and Culture, N.Y: Paulist Press.

Giglioni, S. (1995). New Insights in Evangelization, Maryknoll: Orbis Book.

Hockens, P. D. (2003). Charismatic Renewal Movement in the New International Dictionary of Ministry, London: SCM Press.

Kasper, W. (1982).The God of Jesus Christ, London: Camelot Press Ltd.

Magesa, L. (1997). African Religion: Moral Traditions of Abundant Life, NY: Orbis Books.

Majawa, C. C. A. (2007). The Holy Spirit and the Charismatic Renewal in African and Beyond, Nairobi: Catholic University of Eastern Africa.

Maurer, S.A. (2010). The Spirit of Enthusiasm A History of Charismatic Renewal 1967-2000, New York: University Press of America.

Mbiti, J. (1990). African Religion and Philosophy, 2nd ed. Oxford: Heinemann.

Miller, D. E. (1997).Reinventing American Protestantism, Berkely: University Press (177-190).

Mooney, C.M (2004). What can we learn from the Medieval Church in the in the Catholic in the Catholic Church in the First $21^{\text {St }}$ Century Finding Hope for Its Future in the Wisdom of the Past, 1-11 Ed Himes Michael, Missouri: Liguori.

Orlandis, J. (1993). A Short History of the Catholic Church, Dublin: Four Courts Press.

Parankimalil, J. (2006) Catholic Catechism For All, Nairobi: Vincentian Prayer House.

Stark, D. (1986). Rethinking Internal Labour Market: New Insight from a Comparative perspective in American Psychology Review Vol. 51, NO 4.

Stark, R. B., \& Bain Bridge W. S. (1996). The Future of Religion: Secularization, Revival and Cult Formation, Berkeley: University of California.

Sullivan, F.A.(1982). Charisms and Charismatic Renewal: A Biblical and Theological study, Dublin: Gill and Macmillan.

Shorter, A.\& Njiru, J., (2003). New Religious Movements in Africa, Nairobi: Pauline Publications.

\section{Articles}

Ilo, S. C. (2016). The Church of Pope Francis An Ecclesiology of Accountability, Accompaniment and Action in the Church We Want African Catholics Look To Vatican III, (11-30) Ed Orobator, A.E. Nairobi: Acton Publishers.

Lienhardt R.G. (1982). The Dinka Catholicism in Religious Organization and Religious College Theology Society Annual Vol. 51William Madges (Ed) P 78-99, New York: Orbis Books.

Magesa, L. (2016). Truly African, Fully Christian? the Church we Want African Catholic Look to Vatican III, 79-92 Orobator A.E. ed Nairobi: Acton Publisher. 
Mulago, V. (1969). “Vital Participation: The Cohesive Principle of the Bantu,” Ed Kwesi, A. \& Paul E. Biblical Revelation and African Beliefs, Maryknoll, NY: Orbis Books 137-158.

Omenyo (2002). Pentecostal outside Pentecostalism. A Study of the Development of Charismatic Renewal in the Mainline Churches in Ghana, Amsterdam: Boeken centrum.

\section{Ecclesia Documents}

Catechism of the Catholic Church, (1994), Vaticana: Veritas/ Libereria Edectrice.

Francis (2013), Evangelii Gaudium, Vaticana: Libereria Editrice.

Francis (2013). Evangelii Gaudium Apostolic Exhortation, Vatican: Libraria Editrice.

Gaudium et Spes (1965) in the Vatican II Documents

Lumen Gentium(1965) in the Vatican II Documents

Paul II, J. (1999), Redemptoris Missio, Vaticana: Liberaria Editrice

\section{Website}

http://www.vrcthika.org 23/5/2015 